\title{
Pengaruh Corporate Governance Terhadap Kinerja Perusahaan yang Terdaftar di Bursa Efek Indonesia Tahun 2014 - 2017 (Studi pada Perusahaan yang Memperoleh CGPI Tahun 2014 - 2017)
}

\author{
Eva Setiarini Damanik, Yulia Istia Ningsih \\ Dosen Fakultas Ekonomi Jurusan D3 Akuntansi, Sekolah Tinggi Ilmu Ekonomi Graha Karya \\ E-mail: setia_superior@yahoo.com
}

\begin{abstract}
The objectives of this study is to find out the influence of good corporate governance (GCG) towards the corporate performance. Independent variable in this research is good corporate governance. This variable is measured with an instrument developed by IICG in the form of corporate governance perception index (CGPI). CGPI contains the score of the survey's result related to the application of corporate governance by the Companies throughout Indonesia. Meanwhile the dependent Variable of this research is the Performance of the Company on their finances measured with "return on equity and Tobin's Q. The Sample of this study is company which is registered in Indonesian Stock Exchange and joined CGPI Programs in 2014, 2015, 2016 and 2017 taken by using purposive sampling method. This study used simple linear regression analysis method. The result of this study : (1) Corporate governance has a positive impact on $R O E$ (2) Corporate governance has not an impact on Tobin's $Q$
\end{abstract}

Keywords : Corporate Governance; Return On Equity; Tobin's $Q$

DOI: 10.33087 /ekonomis.v3i1.51

\section{PENDAHULUAN}

Corporate governance merupakan seperangkat peraturan yang mengatur hubungan antara pemegang saham, pengelola perusahaan, pihak kreditur, pemerintah, karyawan serta pemegang kepentingan internal dan eksternal lainnya yang berkaitan dengan hak-hak dan kewajiban mereka, FCGI (2011). Dari definisi tersebut dapat disimpulkan bahwa corporate governance adalah suatu sistem yang dibangun untuk mengarahkan dan mengendalikan perusahaan sehingga terciptanya tata hubungan yang baik, adil dan transparan diantara berbagai pihak yang terkait dan memiliki kepentingan (stakeholder) dalam perusahaan. Salah satu tujuan penting pendirian suatu perusahaan adalah untuk meningkatkan kesejahteraan pemiliknya atau pemegang saham, atau memaksimalkan kekayaan pemegang saham melalui peningkatkan nilai perusahaan (Brigham dan Houston, 2001 dalam Yudha, 2007). Peningkatan nilai perusahaan tersebut dapat dicapai jika perusahaan mampu beroperasi dengan mencapai laba yang ditargetkan. Melalui laba yang diperoleh tersebut perusahaan akan mampu memberikan dividen kepada pemegang saham, meningkatkan pertumbuhan perusahaan dan mempertahankan kelangsungan hidupnya (Yudha, 2007).

Corporate governance merupakan konsep yang diajukan demi peningkatan kinerja perusahaan melalui supervisi atau monitoring kinerja manajemen dan menjamin akuntabilitas manajemen terhadap stakeholder dengan mendasarkan pada kerangka peraturan. Konsep corporate governance diajukan demi tercapainya pengelolaan perusahaan yang lebih transparan bagi semua pengguna laporan keuangan (Sam'ani, 2008). Melalui penerapan good corporate governance tersebut diharapkan: (1) perusahaan mampu meningkatkan kinerjanya melalui terciptanya proses pengambilan keputusan yang lebih baik, meningkatkan efisiensi operasional perusahaan, serta mampu meningkatkan pelayanannya kepada stakeholder, (2) perusahaan lebih mudah memperoleh dana pembiayaan yang lebih murah sehingga dapat meningkatkan corporate value, (3) mampu meningkatkan kepercayaan investor untuk menanamkan modalnya di Indonesia dan (4) pemegang saham akan merasa puas dengan kinerja perusahaan sekaligus akan meningkatkan shareholders value dan dividen. (Adisetiawan dan Surono, 2016)

Sukmawati (2004) meneliti dampak good corporate governance terhadap kinerja. Hasil penelitian ini menunjukan pelaksanaan good corporate governance tidak berpengaruh terhadap kinerja yang tercermin dari nilai pasar perusahaan dilihat dari segi profitabilitas, umur perusahaan dan ukuran perusahaan. Meskipun demikian, penelitian sebelumnya menemukan perbedaan dalam praktik tata kelola perusahaan di berbagai industri, khususnya di pasar negara berkembang. Dita dan Nurzaimah (2009) meneliti pengaruh good corporate governance terhadap kinerja keuangan pada perusahaan. Hasil penelitian menunjukkan good corporate governance tidak mempengaruhi kinerja perusahaan dilihat dari ROI, ROE, dan NPM. Kemungkinan terbesar keadaan ini terjadi karena terbatasnya informasi. Selain itu jika dilihat dari jangka waktunya, GCG lebih bersifat jangka panjang sehingga tidak dapat diukur 
Pengaruh Corporate Governance Terhadap Kinerja Perusahaan yang Terdaftar di Bursa Efek Indonesia Tahun 2014 - 2017 (Studi pada Perusahaan yang Memperoleh CGPI Tahun 2014 - 2017)

kesuksesannya jika hanya mengandalkan satu periode akuntansi saja sedangkan perhitungan profitabilitas lebih bersifat jangka pendek, di mana hasil yang dicapai dari periode tersebut merupakan hasil tambah perusahaan yang dapat berdiri sendiri (Adisetiawan, 2011). Mengacu pada hasil-hasil penelitian empiris yang telah dilakukan, tampak bahwa bukti empiris tersebut menunjukkan betapa pentingnya penerapan good corporate governance dalam mendukung pencapaian tujuan perusahaan. Namun ada juga hasil penelitian yang menunjukkan tidak adanya pengaruh pelaksanaan corporate governance terhadap kinerja.

\section{Kajian Pustaka}

Corporate governance adalah salah satu pilar dari sistem ekonomi pasar. Ia berkaitan erat dengan kepercayaan baik terhadap perusahaan yang melaksanakannya maupun terhadap iklim usaha di suatu negara. Penerapan GCG mendorong terciptanya persaingan yang sehat dan iklim usaha yang kondusif. Oleh karena itu diterapkannya GCG oleh perusahaan-perusahaan di Indonesia sangat penting untuk menunjang pertumbuhan dan stabilitas ekonomi yang berkesinambungan (KNKG, 2006). Forum For Corporate Governance in Indonesia (FCGI) mendefinisikan corporate governance sebagai seperangkat peraturan yang menetapkan hubungan antara pemegang saham, pengelola, pihak kreditur, pemerintah, karyawan, serta para pemegang kepentingan intern dan ekstern lainnya sehubungan dengan hak-hak dan kewajiban mereka, atau dengan kata lain sistem yang mengarahkan dan mengendalikan perusahaan. Di kalangan pebisnis, secara umum, GCG diartikan sebagai tata kelola perusahaan yang baik. Good Corporate Governance (GCG) diartikan pula sebagai sistem yang mengatur dan mengendalikan perusahaan yang menciptakan nilai tambah (value added) untuk semua stakeholder (Sam'ani, 2008).

Pengertian tentang corporate governance dapat dimasukkan dalam dua kategori. Kategori pertama, lebih condong pada serangkaian pola perilaku perusahaan yang diukur melalui kinerja, pertumbuhan, struktur pembiayaan, perlakuan terhadap para pemegang saham, dan stakeholders. Kategori kedua lebih melihat pada kerangka secara normatif, yaitu segala ketentuan hukum baik yang berasal dari sistem hukum, sistem peradilan, pasar keuangan, dan sebagainya yang mempengaruhi perilaku perusahaan. Corporate governance merupakan kumpulan hukum, peraturan dan kaidah yang wajib dipenuhi, yang dapat mendorong kinerja perusahaan bekerja secara efisien, menghasilkan nilai ekonomi jangka panjang yang berkesinambungan bagi para pemegang saham maupun masyarakat sekitar secara keseluruhan. Prinsip-prinsip dasar dari Good Corporate Governance (GCG), yang pada dasarnya memiliki tujuan untuk memberikan kemajuan terhadap kinerja suatu perusahaan.Secara umum, penerapan prinsip good corporate governance secara konkret, memiliki tujuan terhadap perusahaan sebagai berikut: (1) Memudahkan akses terhadap investasi domestik maupun asing; (2) Mendapatkan cost of capital yang lebih murah; (3) Memberikan keputusan yang lebih baik dalam meningkatkan kinerja ekonomi perusahaan; (4) Meningkatkan keyakinan dan kepercayaan dari stakeholders terhadap perusahaan; dan (5) Melindungi direksi dan komisaris dari tuntutan hukum.

Berbagai tujuan tersebut, pemenuhan kepentingan seluruh stakeholders secara seimbang berdasarkan peran dan fungsinya masing-masing dalam suatu perusahaan, merupakan tujuan utama yang hendak dicapai. Prinsip-prinsip utama dari good corporate governance yang menjadi indikator menurut KNKG :

1. Transparansi (Transparency), untuk menjaga obyektivitas dalam menjalankan bisnis, perusahaan harus menyediakan informasi yang material dan relevan dengan cara yang mudah diakses dan dipahami oleh pemangku kepentingan. Perusahaan harus mengambil inisiatif untuk mengungkapkan tidak hanya masalah yang disyaratkan oleh peraturan perundang-undangan, tetapi juga hal yang penting untuk pengambilan keputusan oleh pemegang saham, kreditur dan pemangku kepentingan lainnya.

2. Akuntabilitas (Accountability), perusahaan harus dapat mempertanggungjawabkan kinerjanya secara transparan dan wajar. Untuk itu perusahaan harus dikelola secara benar, 
Pengaruh Corporate Governance Terhadap Kinerja Perusahaan yang Terdaftar di Bursa Efek Indonesia Tahun 2014 - 2017 (Studi pada Perusahaan yang Memperoleh CGPI Tahun 2014 - 2017)

terukur dan sesuai dengan kepentingan perusahaan dengan tetap memperhitungkan kepentingan pemegang saham dan pemangku kepentingan lain. Akuntabilitas merupakan prasyarat yang diperlukan untuk mencapai kinerja yang berkesinambungan.

3. Responsibilitas (Responsibility), perusahaan harus mematuhi peraturan perundangundangan serta melaksanakan tanggung jawab terhadap masyarakat dan lingkungan sehingga dapat terpelihara kesinambungan usaha dalam jangka panjang dan mendapat pengakuan sebagai good corporate citizen.

4. Independensi (Independency), untuk melancarkan pelaksanaan asas GCG, perusahaan harus dikelola secara independen sehingga masing-masing organ perusahaan tidak saling mendominasi dan tidak dapat diintervensi oleh pihak lain.

5. Kewajaran dan Kesetaraan (Fairness), dalam melaksanakan kegiatannya, perusahaan harus senantiasa memperhatikan kepentingan pemegang saham dan pemangku kepentingan lainnya berdasarkan asas kewajaran dan kesetaraan.

\section{METODE}

Penelitian ini menggunakan sumber data historis. Data yang digunakan adalah data sekunder berupa data kuantitatif yang diperoleh dari berbagai sumber. Data sekunder adalah data yang diperoleh secara tidak langsung dari pihak ketiga, melalui media perantara. Data yang diambil adalah data perusahaan yang terdaftar di BEI tahun 2014 sampai tahun 2017 yang masuk dalam CGPI (Corporate Governance Perception Index) tahun 2014, 2015, 2016 dan 2017. Data sekunder tersebut berupa annual report yang didownload di situs www.idx.co.id dan nilai CGPI dari hasil survei The Indonesian Institute for Corporate Governance yang didapat dengan mengirimkan permohonan melalui e-mail. Pengumpulan data dilakukan dengan menggunakan data dokumentasi yaitu data sekunder yang berupa annual report perusahaan yang terdaftar di BEI yang dipublikasikan dan hasil survei CGPI yang berupa nilai corporate governance perusahaan.

Populasi penelitian ini adalah seluruh perusahaan yang termasuk dalam pemeringkatan corporate governance perception index tahun 2014-2017. Sampel dalam penelitian ini adalah perusahaan yang termasuk dalam pemeringkatan corporate governance perception index tahun 2014-2017 dan terdaftar di Bursa Efek Indonesia tahun 2014-2017. Terdapat 12 perusahaan yang memperoleh skor dalam pemeringkatan CGPI tahun 2014, 2015, 2016 dan 2017 yang dilakukan oleh The Indonesian Institute for Corporate Governance (IICG). Metode pengambilan sampel dalam penelitian ini menggunakan metode purposive sampling, yaitu teknik sampling dengan menggunakan pertimbangan dan batasan tertentu sehingga sampel yang dipilih relevan dengan tujuan penelitian (Jogiyanto, 2004). Peneliti menetapkan kriteria pemilihan sampel yang akan diteliti adalah : Perusahaan yang mengikuti survei IICG tahun 2014, 2015, dan 2016 dan Perusahaan terdaftar di Bursa Efek Indonesia tahun 2014, 2015 dan 2016

Tabel 1. Pemilihan Sampel Penelitian

Keterangan Jumlah Perusahaan

Perusahaan yang memperoleh skor pemeringkatan CGPI tahun

2014, 2015, 2016 dan 2017

Dikurangi: Perusahaan yang tidak terdaftar di Bursa Efek

Indonesia tahun 2014, 2015, 2016 dan 2017

\section{Operasional Variabel Penelitian}

Variabel independen penelitian ini adalah corporate governance. Variabel ini diukur dengan menggunakan instrumen yang dikembangkan oleh IICG berupa Corporate Governance Perception Index (CGPI). CGPI berisi skor hasil survei mengenai penerapan corporate governance pada perusahaan-perusahaan yang terdaftar di Bursa Efek Indonesia. CGPI adalah program riset dan pemeringkatan penerapan good corporate governance di Indonesia pada perusahaan 
Pengaruh Corporate Governance Terhadap Kinerja Perusahaan yang Terdaftar di Bursa Efek Indonesia Tahun 2014 - 2017 (Studi pada Perusahaan yang Memperoleh CGPI Tahun 2014 - 2017)

publik. Program ini dilaksanakan sejak tahun 2001 dilandasi dengan pemikiran pentingnya mengetahui sejauh mana perusahaan-perusahaan tersebut telah menerapkan prinsip-prinsip good corporate governance.

Variabel dependen penelitian ini adalah kinerja perusahaan. Dalam penelitian ini kinerja perusahaan diukur dengan menggunakan Tobin's $Q$ sebagai ukuran penelitian pasar dan Return On Equity (ROE) sebagai ukuran kinerja operasional perusahaan. Tobin's $Q$ merupakan salah satu dari beberapa jalur other asset channel yang digunakan oleh Bank Indonesia dalam mempengaruhi perekonomian khususnya dalam mencapai sasaran akhir dari kebijakan moneter yang dikeluarkan yaitu kestabilan harga-harga (tingkat inflasi). Penelitian ini menganalisa mengenai jalur yang melihat harga asset, yang dipegang oleh masyarakat sebagai ekuitas, sebagai indikator untuk mengendalikan tingkat inflasi. Tobin's $Q$ dihitung dengan menggunakan rumus yang dikembangkan Deni dkk (2005) yaitu:

\section{Tobin's $Q=($ MVE+PS+DEBT $) /$ TA}

Dengan : MVE : harga penutupan saham di akhir tahun buku $\mathrm{x}$ banyaknya saham biasa yang beredar; PS : nilai likuidasi dari saham preferen yang beredar; DEBT : (utang lancar-aktiva lancar) + nilai buku sediaan + utang jangka panjang; TA : nilai buku total aktiva. Rumus tersebut disesuaikan dengan kondisi transaksi keuangan perusahaan-perusahaan di Indonesia (Diah, 2008). Dengan demikian, rumus yang digunakan untuk mengukur Tobin's $Q$ menggunakan rumus sebagai berikut :

$$
Q \text { ratio }=\frac{\text { MarketValue of Equity }+ \text { Liabilities }}{\text { Total Asset }}
$$

Nilai pasar ekuitas saham (market value of equity) dihitung dengan mengalikan harga penutupan saham diakhir tahun dengan jumlah lembar saham yang beredar. Menurut James Tobin, bila rasio ini lebih besar dari 1, berarti perusahaan menghasilkan earning dengan rate of return yang sesuai dengan harga perolehan asset-assetnya. ROE (Return On Equity) digunakan untuk mengukur tingkat pengembalian dari total ekuitas. ROE menggambarkan kemampuan modal sendiri untuk menghasilkan keuntungan bagi pemegang saham, karena dalam ROE yang digunakan sebagai pengukur efisiensi adalah besarnya laba bersih dari jumlah modal sendiri yang digunakan perusahaan. Jadi, ROE dimaksudkan untuk mengukur seberapa banyak keuntungan yang menjadi hak pemilik modal (Martono dan Harjito, 2007). ROE dihitung dengan menggunakan rumus sebagai berikut:

$$
\text { ROE }=\frac{\text { Laba Bersih }}{\text { Total Ekuitas }}
$$

\section{Metode Analisis Data}

Metode analisis data yang digunakan dalam penelitian ini adalah analisis regresi linear sederhana. Untuk populasi, persamaan garis linear sederhananya dinyatakan dalam bentuk : $\mu_{\mathrm{y}-\mathrm{x}}=\mathrm{A}+\mathrm{BX}+\varepsilon$

Karena populasi jarang diamati secara langsung, maka digunakan persamaan regresi linear sederhana sampel sebagai penduga persamaan regresi linear sederhana populasi (Iqbal, 2003). Bentuk persamaannya adalah :

$\mathrm{Y}=\mathrm{a}+\mathrm{bX}+\mathrm{e}$

Maka bentuk persamaan linear dalam penelitian ini adalah sebagai berikut :

$\mathbf{Y}=\mathbf{a}+\mathbf{b} \mathbf{C G}+\mathbf{e}$

Keterangan : Y : Return On Equity (ROE); Tobin's Q; CG : Corporate Governance; a : Konstanta; b: Koefisien Regresi; e : Error 
Pengaruh Corporate Governance Terhadap Kinerja Perusahaan yang Terdaftar di Bursa Efek Indonesia Tahun 2014 - 2017 (Studi pada Perusahaan yang Memperoleh CGPI Tahun 2014 - 2017)

\section{Uji Statistik}

Uji Normalitas

Uji Normalitas ini bertujuan untuk menguji apakah dalam model regresi, variabel pengganggu atau residual memiliki distribusi normal. Dalam uji normalitas ini ada dua cara untuk mendeteksi apakah residual berdistribusi normal atau tidak yaitu dengan analisis grafik dan uji statistik.

\section{Uji Heteroskesdastisitas}

Heteroskedastisitas adalah varian residual yang tidak konstan pada regresi sehingga akurasi hasil prediksi menjadi meragukan. Uji heteroskedastisitas bertujuan untuk menguji apakah dalam model regresi terjadi ketidaksamaan variance dari residual satu observasi ke observasi yang lain. Heteroskesdastisitas menggambarkan nilai hubungan antara nilai yang diprediksi dengan studentized delete residual nilai tersebut. Cara memprediksi ada tidaknya heterokedastisitas pada satu model dapat dilihat dari pola gambar Scatterplot model. Analisis pada gambar Scatterplot yang menyatakan model regresi linier berganda tidak terdapat heteroskedastisitas. Model regresi yang baik adalah homoskedastisitas atau tidak terjadi heteroskedastisitas.

\section{Uji Autokorelasi}

Uji autokorelasi bertujuan untuk mengetahui ada tidaknya korelasi antara variabel pengganggu pada periode tertentu dengan variabel pengganggu periode sebelumnya. Autokorelasi muncul karena observasi yang berurutan sepanjang waktu berkaitan satu sama lain. Masalah ini timbul karena residual tidak bebas dari suatu observasi ke observasi lainnya. Model regresi yang baik adalah regresi yang bebas dari autokorelasi.

\section{Uji Hipotesis}

\section{Pengujian Hipotesis Pertama}

Pengujian hipotesis pertama menggunakan formulasi sebagai berikut :

$\mathrm{H}_{01}: \mathrm{b}=\mathbf{0}$ Corporate governance tidak mempengaruhi kinerja keuangan diukur dengan ROE

$\mathrm{H}_{\mathrm{A} 1}: \mathbf{b} \neq 0$ Corporate governance mempengaruhi kinerja keuangan diukur dengan ROE.

Kriteria pengujian yang digunakan untuk menerima atau menolak hipotesis $\mathrm{H}_{\mathrm{A} 1}$ di atas adalah: jika koefisien regresi bmemiliki nilai p-value $<0.05$ maka $\mathrm{H}_{\mathrm{A} 1}$ diterima yang berarti, Penerapan GCG berpengaruh terhadap ROE.

\section{Pengujian Hipotesis Kedua}

Pengujian hipotesis kedua menggunakan formulasi sebagai berikut :

$\mathrm{H}_{02}: \mathrm{b}=\mathrm{O}$ Corporate governance tidak mempengaruhi kinerja kehangan diukur dengan Tobin's $Q$.

$H_{A 2}: b \neq 0$ Corporate governance mempengaruhi kinerja diukur dengan Tobin's $Q$.

Kriteria pengujian yang digunakan untuk menerima atau menolak hipotesis $\mathrm{H}_{\mathrm{A} 2}$ di atas adalah: jika koefisien regresi bmemiliki nilai p-value $<0.05$ maka $\mathrm{H}_{\mathrm{A} 2}$ diterima yang berarti, Penerapan GCG berpengaruh terhadap Tobin's Q

\section{HASIL}

\section{Model 1}

\section{Uji Normalitas}

Uji normalitas dilakukan dengan menggunakan metode PP Plot. Hasil uji normalitas diperoleh sebagai berikut : 


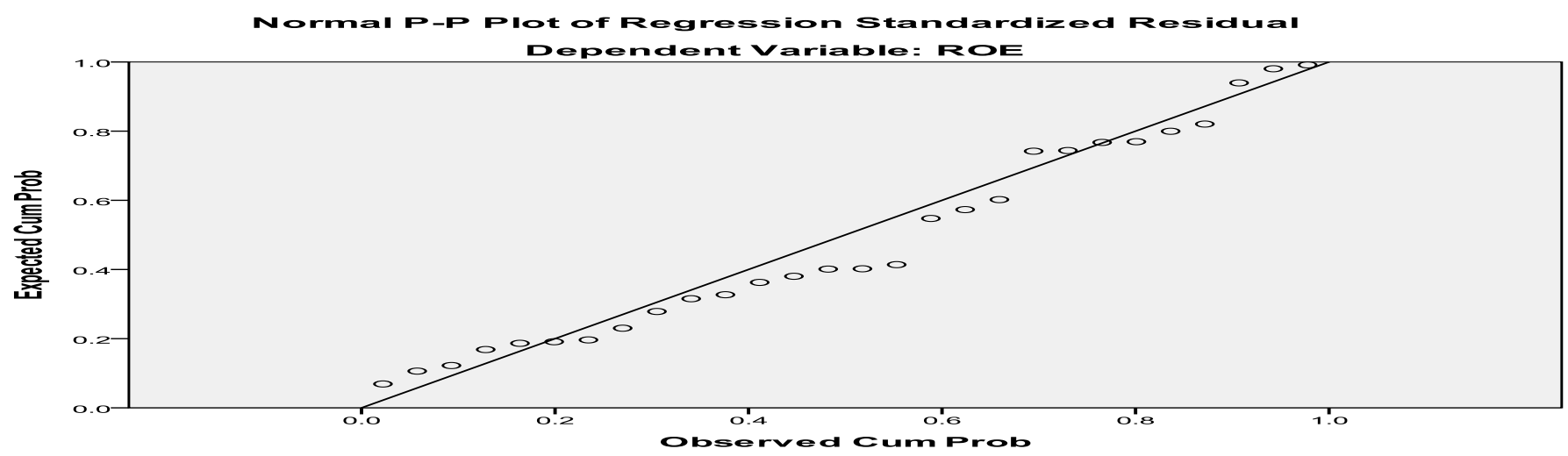

Gambar 1. Uji Normalitas - Model 1

Gambar 1 di atas dapat dilihat titik-titik menyebar mendekati sumbu diagonal, maka ini mengindikasikan ada hubungan antara corporate governance dan ROE. Dalam Plot tersebut tampak titik-titik mengarah dari kiri bawah ke kanan atas ini berarti peningkatan corporate governance juga diikuti oleh peningkatan ROE.

\section{Uji Autokorelasi}

Pengujian autokorelasi dilakukan dengan menggunakan uji Durbin Watson, yaitu dengan membandingkan nilai DW dengan nilai tabel du. Jika DW berada pada rentang du dan $4-d u$, maka hal ini menunjukkan tidak ada masalah autokorelasi dalam model regresi.

Tabel 2. Hasil Pengujian Autokorelasi - Model 1

\begin{tabular}{|l|l|l|l|l|l|}
\hline Model & R & R Square & Adjusted R Square & Std. Error of the Estimate & DW \\
\hline 1 & $.504^{\mathrm{a}}$ & .254 & .225 & 11.09200928 & 1.522 \\
\hline
\end{tabular}

Sumber: data olahan

Hasil pengujian diperoleh nilai $\mathrm{DW}=1.522$, sedangkan nilai dl sebesar 1,3284 dan du diperoleh sebesar 1,4759. Dengan nilai DW > du maka dapat disimpulkan bahwa tidak ada masalah autokorelasi pada model 1 .

\section{Uji Heteroskedastisitas}

Pengujian heteroskedastisitas dilakukan dengan menggunakan Scatter plot. Hasil pengujian pada lampiran sebagaimana juga pada tabel berikut ini menunjukkan bahwa dari hasil pengujian, menunjukkan bahwa pola scatter plot dari regresi menyebar. Hal ini berarti bahwa model regresi tidak memiliki gejala adanya heteroskdastisitas.

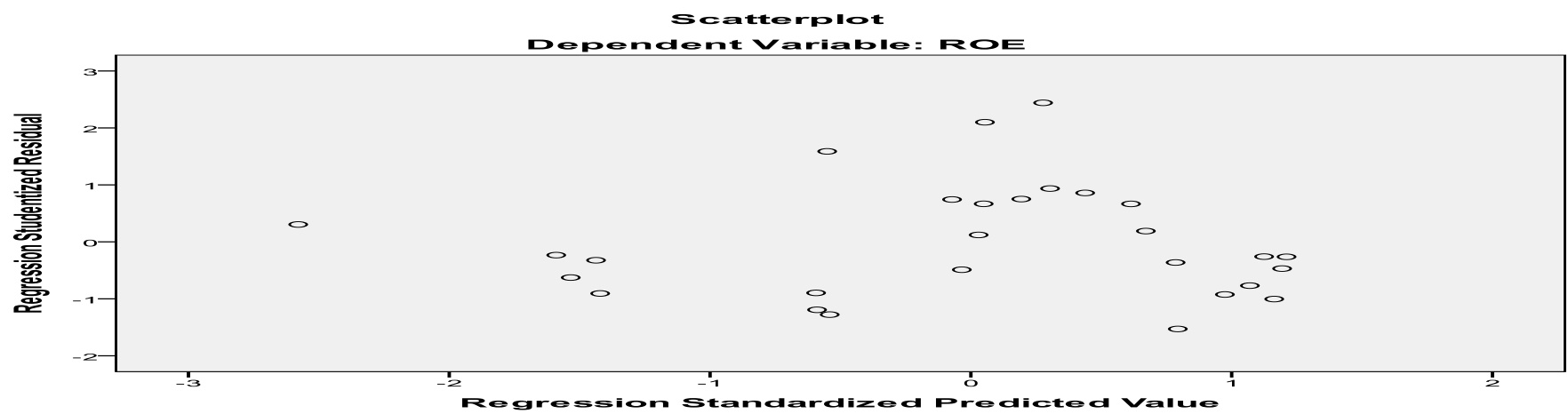

Gambar 2. Uji Heteroskedastisitas - Model 1

\section{Pengujian Hipotesis Pertama}

Pengujian terhadap hipotesis pertama penelitian menggunakan analisis regresi linear sederhana dengan bentuk sebagai berikut: 
Pengaruh Corporate Governance Terhadap Kinerja Perusahaan yang Terdaftar di Bursa Efek Indonesia Tahun 2014 - 2017 (Studi pada Perusahaan yang Memperoleh CGPI Tahun 2014 - 2017)

$\mathbf{Y}=\mathbf{a}+\mathbf{b} \mathbf{C G}+\mathbf{e}$

Keterangan : Y : Return On Equity (ROE); CG : Corporate Governance; a : Konstanta; b : Koefisien Regresi; e : Error

Berdasarkan hasil analisis regresi linear sederhana yang dilakukan dengan program SPSS 19, hasilnya dapat dilihat sebagai berikut:

Tabel 3. Hasil Pengujian Regresi Linier - Model 1

\begin{tabular}{|c|c|c|c|c|c|}
\hline \multirow[b]{2}{*}{ Model } & \multicolumn{2}{|c|}{ Unstandardized Coefficients } & \multirow{2}{*}{\begin{tabular}{|c|} 
Standardized Coefficients \\
Beta
\end{tabular}} & \multirow[b]{2}{*}{ L } & \multirow[b]{2}{*}{ Sig. } \\
\hline & $\mathrm{B}$ & Std. Error & & & \\
\hline $1 \quad$ (Constant) & $\begin{array}{r}-43.442 \\
769\end{array}$ & $\begin{array}{r}21.278 \\
250\end{array}$ & 50 & \begin{tabular}{r|}
-2.042 \\
2972
\end{tabular} & .051 \\
\hline
\end{tabular}

Sumber: Data sekunder diolah.

Berdasarkan hasil analisis regresi yang disajikan dalam Tabel 3 di atas maka dapat dituliskan model regresi sebagai berikut:

$\mathrm{ROE}=-43.442+0.769 \mathrm{CG}+\mathrm{e}$

Nilai intersep regresi di atas sebesar -43.442 hal ini menunjukkan bahwa besarnya nilai ROE perusahaan sampel jika nilai skor $G C G=0$ adalah sebesar -43.442 . Koefisien regresi skor GCG sebesar 0.769 hal ini berarti jika skor GCG meningkat 1 maka ROE perusahaan sampel akan meningkat sebesar 0.769 .

Pengujian hipotesis pertama penelitian ini dilakukan dengan menggunakan formulasi hipotesis sebagai berikut:

$\mathrm{H}_{01}: \mathrm{b}=0$ Corporate governance tidak mempengaruhi kinerja keuangan diukur dengan ROE $\mathrm{H}_{\mathrm{A} 1}: \mathrm{b} \neq 0$ Corporate governance mempengaruhi kinerja keuangan diukur dengan ROE.

Kriteria pengujian yang digunakan untuk menerima atau menolak hipotesis $\left(\mathrm{H}_{\mathrm{A} 1}\right)$ di atas adalah: jika koefisien regresi $b_{1}$ memiliki nilai $p$-value $<0.05$ maka $\mathrm{H}_{\mathrm{A} 1}$ diterima yang berarti, penerapan GCG berpengaruh terhadap ROE. Berdasarkan hasil analisis regresi yang telah dilakukan, besarnya koefisien regresi untuk variabel GCG adalah $b_{1}=0.769, t=2.972, p=0.006$. Pada tingkat signifikansi (a) $5 \%$ atau 0.05 , ternyata nilai $\mathrm{p}(0.006)<\mathrm{a}=0.05$, dengan demikian $\mathrm{H}_{01}$ ditolak dan $\mathrm{H}_{\mathrm{A} 1}$ diterima. Hal ini menunjukkan bahwa hipotesis pertama penelitian ini dapat diterima kebenarannya.

Kesimpulan dari hasil pengujian hipotesis yang telah dilakukan ini adalah: penerapan GCG oleh perusahaan sampel berpengaruh positif terhadap ROE. Jika skor penerapan GCG meningkat 1 maka ROE perusahaan sampel akan meningkat sebesar 0.769.

\section{Pengaruh Corporate Governance terhadap Kinerja Perusahaan Diukur dengan Return On Equity (ROE)}

Hipotesis pertama menyatakan bahwa "corporate governance berpengaruh terhadap return on equity". Hasil pengujian statistik menunjukkan tingkat signifikan corporate governance sebesar 0.006 yang lebih kecil dari tingkat signifikan 0.05 sehingga dapat membuktikan bahwa corporate governance berpengaruh terhadap kinerja perusahaan yang diukur dengan ROE.

\section{Pengaruh Corporate Governance terhadap Kinerja Perusahaan Diukur dengan Tobins $Q$}

Hipotesis kedua menyatakan bahwa "corporate governance berpengaruh terhadap Tobins $Q "$. Hasil pengujian statistik menunjukkan tingkat signifikan Tobins $Q$ sebesar 0.321 yang lebih besar dari tingkat signifikan 0.05 sehingga tidak dapat membuktikan bahwa corporate governance berpengaruh terhadap kinerja keuangan yang diukur dengan Tobins $Q$. Hal ini menunjukkan bahwa corporate governance belum sepenuhnya berpengaruh terhadap Tobins $Q$. Ini dapat disebabkan oleh penerapan corporate governance yang memerlukan waktu sebelum dapat melihat pengaruh dari penerapannya, lalu kemungkinan disebabkan rendahnya kesadaran emiten dalam menerapkan GCG, Manajemen perusahaan belum tertarik manfaat 
Pengaruh Corporate Governance Terhadap Kinerja Perusahaan yang Terdaftar di Bursa Efek Indonesia Tahun 2014 - 2017 (Studi pada Perusahaan yang Memperoleh CGPI Tahun 2014 - 2017)

jangka panjang penerapan GCG karena Mereka merasa dapat berjalan tanpa GCG, Manajemen perusahaan belum melihat adanya dampak finansial secara langsung, masalah kepemilikan yang sebagian masih terkonsentrasi pada perorangan atau keluarga pendiri dan unsur budaya yang berkembang dilingkungan usaha nasional belum menunjang perkembangan penerapan GCG karena perusahaan masih beranggapan bahwa transparansi berarti membuka rahasia dagang dan bisa mengancam daya saing.

\section{SIMPULAN}

berikut:

hasil pengujian analisis regresi linear sederhana maka dapat disimpulkan sebagai

1. Hasil pengujian analisis regresi linear sederhana menunjukkan bahwa secara statistik penerapan GCG oleh perusahaan sampel berpengaruh positif :hadap ROE. Dengan demikian hipotesis $\mathrm{H}_{01}$ ditolak dan $\mathrm{H}_{\mathrm{A} 1}$ diterima.

2. Hasil pengujian analisis regresi linear sederhana menunjukkan bahwa secara statistik penerapan GCG oleh perusahaan sampel tidak berpengaruh terhadap Tobins Q. Dengan demikian hipotesis $\mathrm{H}_{02}$ diterima dan $\mathrm{H}_{\mathrm{A} 2}$ ditolak.

\section{DAFTAR PUSTAKA}

Adisetiawan, R., and Surono, Yunan, 2016, Earnings Management and Accounting Information Value: Impact and Relevance, Business, Management and Economics Reseach, 2(10), 170179

Adisetiawan, R., 2011, Relevansi Nilai Informasi Akuntansi pada Indeks LQ45, Jurnal Akuntabilitas, 1(1), 119-136

Deni Darmawati, Khomsiyah, dan Rika Gelar Rahayu. 2005. Hubungan Corporate Governance dan Kinerja Perusahaan. Jurnal Riset Akuntansi Indonesia 8.

Diah Kusuma Wardani. 2008. Pengaruh Corporate Governance Terhadap Kinerja Perusahaan di Indonesia. Skripsi, Sarjana Akuntansi, Universitas Islam Indonesia : Yogyakarta

Dita Paradita dan Nurzaimah. 2009, Pengaruh Good Corporate Governance Terhadap Kinerja Keuangan Pada Perusahaan Yang Termasuk Kelompok Sepuluh Besar Menurut Corporate Governance Perception Index (Cgpi). Jurnal Akuntansi, 40, Universitas Sumatera Utara.

Iqbal Hasan, M., 2003. Pokok-Pokok Materi Statistik 2 (Statistik Inferensif). Bumi Aksara : Jakarta.

Martono dan Agus Harjito. 2007. Manajemen Keuangan. Ekonisia : Kampus Fakultas Ekonomi UII Yogyakarta.

Sam'ani. 2008. Pengaruh Good Corporate Governance Dan Leverage Terhadap Kinerja Keuangan Pada Perbankan Yang Terdaftar Di Bursa Efek Indonesia (BEI) Tahun 2004 - 2007. Tesis, Sarjana S-2 Magister Manajemen Universitas Diponegoro : Semarang.

Yudha Pranata. 2007. Pengaruh Penerapan Corporate Governance Terhadap Kinerja Perusahaan. Skripsi, Sarjana Akuntansi, Universitas Islam Indonesia : Yogyakarta. 